\title{
PENYALAHGUNAAN WEWENANG POLRI DALAM PEMBERANTASAN TINDAK PIDANA PERJUDIAN (STUDI KASUS DI POLDA BALI)
}

\author{
Gusti Partana Mandala(1) \\ partanamandala@undiknas.ac.id ${ }^{(1)}$
}

\section{Fakultas Hukum dan Ilmu Sosial Undiknas Denpasar}

\begin{abstract}
Penalty of gambling has been carried out against the law and prohibited by religion because it can plunge someone into destruction, Criminal gambling in the Law of the Republic of Indonesia Number 7 of 1974 concerning Control of Gambling, easily develops the community directed there. to be overcome because of the lack of awareness of the people themselves about the regulations that have been made, coupled with law enforcement officials who are more aware of the rules often act on their authority by misusing authority. There are members of the Bali regional police (POLDA BALI) involved in criminal acts, which causes $P O L R I$ to have the authority to develop initiatives in Article 15 paragraph (1) letter e of Law No. 2 of 2002 concerning the Indonesian National Police. Research Methods The law of this research starts from primary / basic data, namely data obtained directly from the community as the first. The results of this study are that the police involved in the field of police in Bali is an optimal one, because every member of the Indonesian republican police is based on TRIBRATA and CATUR PRASETYA which regulates morals and conscience guides for every member of the Republic of Indonesia National Police, It can also apply to other police functions. Members of the Indonesian republic's police force involved in legal cases made under the Bali regional police, which are based on ANKUM's policy.

Keywords: Criminal Acts of Gambling, Abuse of authority, Members of the Bali Regional Police.
\end{abstract}

\begin{abstract}
ABSTRAK
Tindak pidana perjudian merupakan suatu perbuatan melawan hukum serta dilarang oleh agama karena dapat menjerumuskan seseorang pada kehancuran, Tindak pidana perjudian diatur dalam Undang-Undang Negara Republik Indonesia Nomor 7 Tahun 1974 Tentang Penertiban Perjudian, perjudian dengan mudah berkembang dikalangan masyarakat yang menyebabkan praktek perjudian tersebut sulit untuk diatasi karena kesadaraan dari masyarakat sendiri yang sangat kurang terhadap peraturan yang telah dibuat, apalagi dengan aparat penegak hukum yang lebih paham akan peraturan sering bertindak melampaui wewenangnya dengan menyalahgunakan wewenang. Adanya anggota kepolisian daerah Bali (POLDA BALI) yang terlibat dalam tindak pidana perjudian, yang seharusnya POLRI memiliki wewenang untuk mencegah perkembangan perjudian yang diatur dalam Pasal 15 ayat (1) huruf e Undang-Undang No. 2 Tahun 2002 Tentang Kepolisian Negara Republik Indonesia. Metode Penelitian Hukum empiris penelitian lapangan ini bertitik tolak dari data primer/dasar, yakni data yang diperoleh langsung dari masyarakat sebagai sumber pertama dengan melalui penelitian lapangan. Hasil dari penelitian ini oknum kepolisian yang terlibat tindak pidana perjudian di kepolisian daerah Bali disebabkan kurangnya pengawasan yang optimal, karena
\end{abstract}


setiap anggota kepolisian Negara republik indonesia berdasar pada TRIBRATA dan CATUR PRASETYA yang dimana mengatur pedoman moral dan penuntun nurani bagi setiap anggota kepolisian Negara republik Indonesia, serta dapat pula berlaku bagi pengemban fungsi kepolisian lainnya. Anggota kepolisian Negara republik Indonesia yang terlibat tindak pidana perjudian dijatuhkan sanksi disiplin ditingkat kepolisian daerah bali, yang berdasarkan kebijakan dari ANKUM.

Kata Kunci: Tindak pidana Perjudian, Penyalahgunaan wewenang, Anggota Kepolisian daerah Bali.

\section{PENDAHULUAN}

Perjudian merupakan suatu perbuatan yang melawan hukum, perjudian sudah sangat jelas diatur dalam Undang-Undang Nomor 7 Tahun 1974 Tentang Penertiban Perjudian, dalam Pasal 1 menyebutkan bahwa semua tindak pidana perjudian sebagai kejahatan. Dalam konsideran disebutkan bahwa perjudian pada hakekatnya bertentangan dengan agama, kesusilaan dan moral, serta membahayakan bagi kehidupan masyarakat, bangsa dan Negara.

Penegak Hukum di Indonesia itu ada empat yaitu salah satunya adalah Kepolisian Negara Republik Indonesia atau yang sering disingkat dengan POLRI, Undang-Undang POLRI diatur dalam Undang-Undang Kepolisian

Negara Republik Indonesia Nomor 2 Tahun 2002 yang ditugaskan oleh Undang-Undang untuk pemeliharaan keamanan dan ketertiban masyarakat, penegakan hukum, perlindungan, pengayoman, dan pelayanan kepada masyarakat, yang bertujuan untuk mewujudkan ketentraman di dalam masyarakat dengan menjunjung tinggi hak asasi manusia. Namun pada kenyataannya banyak pelanggaran - pelanggaran atau penyimpangan yang dilakukan oleh oknum kepolisian atau dikenal dengan istilah "maladministrasi".

Penyalahgunaan wewenang yang dilakukan oknum kepolisian dengan terlibat dalam praktek perjudian yang dimana tindakan tersebut merupakan salah satu bentuk kejahatan yang tercantum pada rumusan KUHP yang diatur dalam Pasal 303 dan 303 bis, setelah dikeluarkannya Undang-Undang Nomor 7 Tahun 1974 tentang Penertiban Perjudian. ${ }^{1}$

Prilaku dari oknum kepolisian sangat disayangkan dalam hal ini

${ }^{1}$ Ridwan H.R., 2011, Hukum Administrasi Negara Edisi Revisi, Rajawali Pers, Jakarta, hal 99. 
justru oknum kepolisian ikut terlibat didalam perjudian, adapun oknumoknum kepolisian yang telah ditindak oleh PROVOS POLDA Bali karena telah melakukan pelanggaran yang dimana oknum kepolisian terlibat dalam kasus perjudian dan sudah diproses sesuai dengan prosedur dan aturan yang berlaku, untuk jumlahnya tidak dapat disebutkan, karena merupakan data yang bersifat rahasia. Menurut penuturan Ajun Komisaris Polisi) AKP Wayan Subratha S.H.,MH. Sebagai KANIT RIKSA SUBBID PROVOS BIDPROPAM POLDA BALI pada saat diwawancarai menyatakan bahwa tingkat pelanggaran khususnya dalam perjudian ditahun 2017 yang dilakukan oknum kepolisian dengan rata-rata berpangkat Bintara POLRI sejumlah $0, \ldots \%$, presentasenya. Beliau juga menuturkan bahwa tingkat kasus penyalahgunaan wewenang oleh oknum kepolisian yang terlibat dalam perjudian ditahun 2017 terdapat penurunan dari tahun sebelumnya dan apabila ditemukan oknum kepolisian yang melakukan tindak pidana atau yang bersifat melawan hukum akan ditindak tegas dan diperoses sesuai prosedur dan aturan yang berlaku. ${ }^{2}$ Praktek-praktek perjudian yang berkembang dimasyarakat harus diberantas, dalam hal ini POLRI memiliki wewenang secara mutlak untuk mencegah perkembangan penyakit masyarakat tersebut. Karena bagaimanapun juga perjudian adalah perbuatan melawan hukum dan harus diberantas supaya tidak menjadi berkesinambungan.

\section{PEMBAHASAN}

\section{Penyebab Terjadinya Penyalahgunaan Wewenang Polri Dalam}

\section{Pemberantasan Tindak Pidana Perjudian.}

Ditinjau dari teori kewenangan, penulis sependapat dengan teori H.D. Van Wijk/Willem Konijnenbelt dan H.D Stout untuk membahas permasalahan dari penyebab-penyebab terjadinya penyalah gunaan wewenang oleh oknum kepolisian dalam pemberantasan tindak pidana judi, yang dimana suatu kewenangan merupakan hak menggunakan wewenang yang dimiliki seorang pejabat atau institusi menurut ketentuan yang berlaku, dengan demikian kewenangan juga menyangkut kompetensi tindakan hukum yang dapat dilakukan menurut kaedah-kaedah formal, jadi

2hasil wawancara dengan, bapak Wayan Subratha selaku KANIT RIKSA SUBBID PROVOS BIDPROPAM POLDA BALI, pada tanggal 17 Oktober 2017. 
kewenangan merupakan kekuasaan formal yang dimiliki oleh pejabat atau institusi ${ }^{3}$. Karena pada dasarnya POLRI diberi wewenang secara atribusi oleh Undang-Undang yaitu dalam Pasal 15 ayat (1) huruf e Undangundang No. 2 Tahun 2002 menyatakan "Mencegah dan menanggulangi tumbuhnya penyakit masyarakat". Namun pada kenyataannya adanya penyimpangan dari penerapan Undang-undang yang dilakukan oknumoknum kepolisian yang terlibat dalam praktek perjudian. Maka dapat dikatakan oknum kepolisian tersebut menyimpang dari wewenang yang telah diberikan oleh Undang-undang khususnya dalam upaya menegakkan hukum.

Berdasarkan hasil wawancara dengan AKP Wayan Subratha S.H.,MH. Sebagai KANIT RIKSA SUBBID PROVOS BIDPROPAM POLDA BALI menuturkan bahwa tindakan oknum kepolisian yang terlibat didalam tindak pidana perjudian tidak lain penyebabnya adalah lemahnya mental dan moral dari oknum kepolisian itu sendiri, karena setiap anggota POLRI maupun pegawai negeri pada POLRI sudah diatur garis norma dan sudah jelas sanksinya. ${ }^{4}$ Anggota POLRI yang terlibat Tindak Pidana Perjudian telah melanggar ketentuan Etika Kepribadian yang tercantum pada Pasal 3 huruf (b) dan (c) Peraturan Kepala Kepolisian Indonesia No. Pol. : 7 Tahun 2006 Tentang Kode Etik Kepolisian Negara Republik Indonesia, yang menyebutkan menjungjung tinggi sumpah sebagai anggota POLRI, dengan melaksanakan tugas kenegaraan dan kemasyarakatan dengan niat murni yang berdasarkan pada TRIBRATA dan Catur Prasetya POLRI. Menurut pendapat penulis masih lemahnya kualitas (SDM) atau sumber daya manusia dari aparat itu sendiri dalam artian kurangnya adanya pelatihanpelatihan mengenai tindak pidana tertentu, selain itu pada saat penerimaan menjadi anggota POLRI dari tingkat Sekolah Menengah Atas (SMA) juga menjadi penyebab kurangnya sumber daya manusia dari aparat itu sendiri.

Kode Etik Profesi Kepolisian (KEPP) disahkan dengan Keputusan Kapolri No. Pol: Kep/32/VII Tanggal 1 Juli 2003 meliputi 3 (tiga) kelompok nilai moral etika terdiri dari beberapa moral dengan pedoman pengamalan bhakti Dharma Waspada, pedoman seorang polisi adalah Insan Rastra

${ }^{3}$ Miriam Budiardjo, 2008, Dasar-dasar IImu Politik, Gramedia Pustaka Utama, Jakarta, h. 60.

${ }^{4}$ hasil wawancara dengan, bapak Wayan Subratha selaku KANIT RIKSA SUBBID PROVOS BIDPROPAM POLDA BALI, pada tanggal 17 Oktober 2017. 
Sewakotama yang artinya POLRI adalah Abdi Utama dari pada Nusa dan Bangsa, Janatama dan Casanadharma.

Setiap Anggota Kepolisian Republik Indonesia adalah Insan Rastra Sewakotama.

1. Mengabdi pada nusa dan bangsa dengan penuh ketaqwaan kepada Tuhan Yang Maha Esa;

2. Berbakti demi keagungan nusa dan bangsa yang bersendikan Pancasila dan Undang-Undang Dasar 1945 sebagai kehormatan yang tertinggi;

3. Membela tanah air, mengamankan dan mengamalkan Pancasila dan Undang-Undang Dasar 1945 sebagai kehormtan yang tertinggi;

4. Menegakkan hukum dan menghormati kaidah-kaidah yang hidup didalam masyarakat secara adil dan bijaksana;

5. Melindungi, mengayomi serta membimbing masyarakat sebagai wujud panggilan tugas pengayoman yang luhur;

Setiap Anggota Kepolisian Republik Indonesia adalah Insan Janatama.

1. Berdharma untuk menjamin ketentraman umum bersama-sama warga masyarakat membina demi terwujudnya kegairahan kerja dan kesejahteraan lahir batin;

2. Menampilkan dirinya sebagai warga Negara yang berwibawa dan dicintai oleh sesame warga negara;

3. Bersikap disiplin, percaya diri, tanggung jawab,penuh keikhlasan dalam tugas kesanggupan, serta selalu menyadari bahwa dirinya adalah warga masyarakat;

4. Selalu peka dan tanggap dalam tugas, mengembangkan kemampuan dirinya, menilai tinggi mutu kerja penuh keaktifan dan efisiensi serta menempatkan kepentingan tugas secara wajar di atas kepentingan pribadinya;

5. Menumpuk rasa persatuan, kesatuan dan kebersamaan serta kesetia kawanan dalam lingkungan masyarakat;

6. Menjauhkan diri dari perbuatan dan sikap tercela serta mempelopori setiap tindakan mengatasi kesulitan-kesulitan masyarakat sekelilignya;

Setiap Anggota Kepolisan Republik Indonesia adalah Insan Casanadharma.

1. Selalu waspadah, siap sedia dan sanggup menghadapi setiap kemungkinan dalam tugas; 
2. Mampu mengendalikan diri dari perbuatan-perbuatan penyalahgunaan;

3. Tidak mengenal berhenti dalam memberantas kejahatan dan mendahulukan cara-cara pencegahan dari pada peda penindakan secara hukum;

4. Memelihara dan mementingkan peran serta masyarakat dalam upaya memelihara ketertiban dan keamanan masyarakat;

5. Bersama-sama segenap komponen kekuatan pertahanan keamanan lainnya dan peran serta masyarakat, memelihara dan meningkatkan kemanunggalan ABRI-rakyat;

6. Meletakkan setiap langkah tugas sebagai bagian dari pencapaian tujuan pembangunan nasional sesuai dengan amanat penderitaan rakyat.

Kode etik profesi kepolisian secara jelas diatur dalam Keputusan Kapolri No. Pol: Kep/32/VII Tanggal 1 Juli 2003 yang menjadi pedoman dasar oleh anggota POLRI didalam bertingkahlaku dan beretika dimasyarakat, diatas juga disebutkan dalam insan janatama yang berbunyi "mampu mengendalikan diri dari perbuatan-perbuatan penyalah gunaan" namun pada pelaksanaannya adanya oknum-oknum kepolisian yang menyimpang dalam melaksanakan profesinya sebagai anggota POLRI yang terlibat dalam tindak pidana perjudian.

\section{Akibat hukum bilamana anggota polri terlibat dalam tindak pidana perjudian.}

Terkait dengan penjatuhan hukum kepada anggota POLRI yang melakukan tindak pidana khususnya perjudian akan diproses melalui peradilan umum, sidang disiplin dan sidang kode etik, karena berdasarkan pada Pasal 29 Undang-Undang Nomor 2 Tahun 2002 tentang Kepolisian Negara Republik Indonesia bahwa anggota POLRI tunduk pada Peradilan Umum dan perlu diketahui penjatuhan sanksi kepada anggota POLRI tidak menghapus tuntutan pidana terhadap anggota polisi yang bersangkutan, yang diatur dalam Pasal 12 ayat (1) PP 2/2003 jo. Pasal 28 ayat (2) Perkapolri 14/2011 yang menyebutkan "Penjatuhan sanksi Kode Etik Profesi POLRI (KEPP) tidak menghapus tuntutan pidana dan/ perdata". Dalam penerapan penjatuhan sanksi terhadap anggota POLRI khususnya dalam penjatuhan sanksi kode etik profesi POLRI tidak menghapus tuntutan pidana artinya akan diproses secara administratif dan diproses 
secara pidana.

Sanksi yang dijatuhkan kepada oknum kepolisian yang melakukan pelanggaran ada 2 yaitu sanksi pelanggaran kode etik profesi POLRI dan sanksi pelanggaran disiplin POLRI, sanksi pelanggaran kode etik diatur dalam Peraturan Kapolri (Perkap) No 14 Tahun 2011 tentang Kode Etik Profesi POLRI Pasal 21 dijelaskan bahwa ada 7 jenis sanksi pelanggaran Kode Etik Profesi POLRI.

1. Perilaku Pelanggar dinyatakan sebagai perbuatan tercela sanksi ini merupakan sanksi tertulis yang menyatakan bahwa perbuatan pelanggar telah menciderai nilai-niai kode etik profesi POLRI.

2. Kewajiban Pelanggar untuk meminta maaf secara lisan dihadapan Sidang KKEP dan/atau secara tertulis kepada pimpinan POLRI dan pihak yang dirugikan; șépisanksi ini bersifat perintah dan harus dilakukan oleh pelanggar kepada pihak yang dirugikan.

3. Kewajiban Pelanggar untuk mengikuti pembinaan mental kepribadian, kejiwaan, keagamaan dan pengetahuan profesi, sekurang-kurangnya 1 (satu) minggu dan paling lama 1 (satu) bulan; is isepisanksi ini bersifat perintah yang ditujukan untuk membina mental kepribadian pelanggar sehingga dapat sejalan kembali dengan nilai-nilai kode etik profesi POLRI.

4. Dipindahtugaskan ke jabatan berbeda yang bersifat Demosi sekurangkurangnya 1 (satu) tahun; ispepsanksi ini bersifat rekomendasi dimana pelanggar direkomendasikan untuk dimutasi dari jabatan yang sedang diduduki.

5. Dipindahtugaskan ke fungsi berbeda yang bersifat Demosi sekurangkurangnya 1 (satu) tahun; iscep sanksi ini bersifat rekomendasi dimana pelanggar direkomendasikan untuk dimutasi dari satuan fungsi asal ke satuan fungsi yang lain.

6. Dipindahtugaskan ke wilayah berbeda yang bersifat Demosi sekurangkurangnya 1 (satu) tahun; sanksi ini bersifat rekomendasi dimana pelanggar direkomendasikan untuk dimutasi dari wilayah hukum satu ke wilayah hukum yang lain.

7. PTDH sebagai anggota Polri. Sanksi ini dijatuhkan isépiapabila terdapat kondisi antara lain: terduga pelanggar dihukum pidana penjara berdasarkan putusan pengadilan yang telah mempunyai kekuatan 
hukum tetap, diketahui memberikan keterangan palsu saat mendaftar sebagai anggota Polri, melakukan usaha atau perbuatan yang bertujuan mengubah Pancasila dan menentang negara, menjadi anggota partai politik, dijatuhi hukuman disiplin lebih dari 3 kali, dan lainnya sesuai yang tercantum dalam pasal 21 ayat (3).

Selain diatur dalam peraturan kode etik profesi POLRI, tingkah laku anggota juga diatur dalam peraturan disiplin yang harus ditaati. Apabila anggota tersebut melanggar peraturan disiplin maka anggota akan dikenakan sanksi disiplin sesuai dengan yang diamanatkan dalam PP No 2 tahun 2003 tentang Peraturan Disiplin Anggota Kepolisian Negara Republik Indonesia. Bagi anggota yang melanggar peraturan disiplin maka dapat dikenakan sanksi berupa tindakan disiplin atau hukuman disiplin.

1. Teguran tertulis; Penundaan mengikuti pendidikan paling lama 1 tahun;

2. Penundaan kenaikan gaji berkala artinya Hukuman disiplin yang berupa penundaan gaji berkala, ditetapkan sekurang-kurangnya 3 (tiga) bulan dan untuk paling lama 1 (satu) tahun. Masa penundaan kenaikan gaji berkala tersebut dihitung penuh untuk kenaikan gaji berkala berikutnya.

3. Penundaan kenaikan pangkat untuk paling lama 1 tahun artinya penundaan kenaikan pangkat dalam arti ditunda usul kenaikan pangkatnya atau ditunda pelantikan pangkatnya.

4. Mutasi yang bersifat demosi artinya yang dimaksud dengan "mutasi yang bersifat demosi" ialah mutasi yang tidak bersifat promosi jabatan.

5. Pembebasan dari jabatan artinya pembebasan dari jabatan dalam arti pembebasan dari jabatan struktural. Pembebasan dari jabatan berarti pula pencabutan segala wewenang yang melekat pada jabatan itu. Selama pembebasan dari jabatan, anggota Kepolisian Negara Republik Indonesia yang bersangkutan menerima penghasilan penuh, kecuali tunjangan jabatan.

6. Penempatan dalam tempat khusus paling lama 21 hari artinya "tempat khusus"yang dimaksud adalah dapat berupa markas, rumah kediaman, ruangan tertentu, kapal, atau tempat yang ditunjuk oleh Ankum

Ditinjau dari teori kemanfaatan, penulis sependapat dengan teori yang dikemukakan oleh beberapa ahli yaitu Jeremi Bentham, John Stuar 
Mill dan Rudolf von Jhering ${ }^{5}$ teori ini penulis gunakan untuk membahas permasalahan dari akibat hukum yang diterima oleh oknum kepolisian bilamana anggota POLRI terlibat dalam praktek perjudian yang dimana teori tersebut menekankan bahwa dasar yang paling objektif adalah dengan melihat apakah suatu kebijakan atau tindakan tertentu membawa manfaat atau hasil yang berguna atau, sebaliknya, karena pada dasarnya fungsi adanya POLRI ialah terpeliharanya keamanan, ketertiban serta tegaknya hukum sesuai dengan cita-cita Negara hukum yang tekandung dalam Undang - Undang Dasar Negara Republik Indonesia Tahun 1945 bukanlah sekedar Negara yang berlandaskan sembarang hukum. Hukum yang didambakan bukanlah hukum yang ditetapkan semata-mata atas dasar kekeuasaan, sehingga jelas bahwa kekuasaan tidak memiliki kebebasan secara mutlak dalam menjalankan kekuasaannya, namun bila adanya oknum - oknum kepolisian yang dengan sengaja melakukan tindakan yang menyimpang dari tugas dan wewenangnya sehingga manfaat yang diterima oleh masyarakat tidak akan pernah terwujud. Maka akibat hukum atau sanksi yang diberikan kepada Oknum-oknum kepolisian yang menyimpang harus diberikan sanksi yang tegas sehingga terciptanya POLRI yang sesuai dengan fungsinya. ${ }^{6}$

Hasil pengumpulan data di POLDA BALI, hanya membahas dalam ruang lingkup POLDA BALI saja, jika ditemukan anggota POLRI yang melakukan pelanggaran maka yang berwenang menindak adalah atasan yang berhak menghukum (ANKUM) di POLDA BALI dimana diatur dalam Pasal 7 PERKAP No. 2 Tahun 2016 Tentang Penyelesaian Pelanggaran Disiplin Anggota Kepolisian Negara Republik Indonesia ditingkat POLDA.

Penerapan penjatuhan sanksi kepada oknum kepolisian yang terlibat dalam tindak pidana perjudian adalah berdasarkan pada ANKUM, jadi atasan yang berhak menghukumlah yang berwenang menjatuhkan sanksi kepada bawahannya yang melakukan pelanggaran disiplin maupun pelanggaran etika profesi ditingkat POLDA.

Proses penanganan kasus baik pelanggaran dan tindak pidana perjudian yang dilaporkan, ditemukan, dan tertangkap tangan akan

5 Philipus M. Hadjon, 1998, Tentang Wewenang Pemerintahan (Bestuursbevoegdheid), Pro Justitia Tahun XVI Nomor 1, Januari 1998, h. 91.

${ }^{6}$ Munir Fuady, 2009, Teori Negara Hukum Modern (Rechtstaat), Refika Aditama, Bandung, 104. 
diperiksa oleh Provos untuk dibuatkan pemberkasan dalam bentuk Berita Acara Pemeriksaan (BAP) dan diserahkan kepada ANKUM. Provos melakukan hal tersebut atas perintah Ankum sesuai dengan Pasal 19 Peraturan Pemerintah Nomor 2 Tahun 2003 yang menyebutkan "Ankum berwenang memerintahkan Provos Kepolisian Negara Republik Indonesia untuk melakukan pemeriksaan terhadap anggota Kepolisian Negara Republik Indonesia yang disangka melakukan pelanggaran disiplin". ${ }^{7}$ Provos dalam penerapan pasal terhadap kasus terlibat dalam suatu perjudian dikenakan pasal 5 huruf (g) yang berbunyi "bertindak sebagai pelindung di tempat perjudian, prostitusi, dan tempat hiburan". Peraturan Pemerintah Nomor 2 Tahun 2003 yaitu mengenai pelanggaran disiplin Polri.

Berdasarkan Pasal 21 UU Nomor 2 Tahun 2002 tentang Kepolisan Negara Republik Indonesia dan Pasal 28 Kep.Kapolri Nomor Pol: Kep/43/X/2004 Ankum diharuskan untuk meminta saran dan pendapat hukum kepada fungsi Pembina Hukum dalam hal ini Bidang Pembinaan Hukum. ${ }^{8}$ Bidang Pembinaan Hukum dalam penerapan Pasal terlibat dalam praktek perjudian dikenakan Pasal 5 huruf (g) yang berbunyi "bertindak sebagai pelindung di tempat perjudian, prostitusi, dan tempat hiburan". Peraturan Pemerintah Nomor 2 Tahun 2003 tentang Peraturan Disiplin Polri. Perjudian juga merupakan tindak pidana yang diatur dalam Kitab Undang-Undang Hukum Pidana (KUHP). Hal tersebut haruslah jelas karena berdasarkan pada Pasal 29 Undang-Undang Nomor 2 Tahun 2002 tentang Kepolisian Negara Republik Indonesia bahwa anggota POLRI tunduk pada Peradilan Umum, sehingga dapat dilakukan sidang disiplin dan atau dilanjutkan untuk diproses secara pidana.

Pemberian saran pendapat hukum yang sudah selesai, berkas perkara dikembalikan kepada Ankum/ Provos, yang selanjutnya kewenangan untuk dilaksanakan atau tidaknya sidang disiplin dan untuk dilanjutkan ke Peradilan Umum adalah keputusan dari Ankum. Apabila

${ }^{7}$ Pramutyas Varentina," Penjatuhan Hukuman Disiplin Polri Di Sekolah Polisi Negara Purwokerto (Kajian Terhadap Penerapan PP Nomor 2 Tahun 2003Tentang Peraturan Disiplin Anggota Kepolisian Republik Indonesia) Skripsi, Perpustakaan fakultas hukum Universitas Jendral Soedirman,Porwokerto, h.92.

${ }^{8}$ ibid, h.91. 
Ankum menghendaki untuk dilaksanakan sidang disiplin, maka Provos yang bertugas untuk melaksanakan sidang disiplin atas perintah Ankum. Namun bila akan diajukan ke Peradilan Umum, maka Provos membuat surat pengantar untuk diserahkan ke Reskrim guna dilakukan penyelidikan dan diproses secara pidana. ${ }^{9}$

Berdasarkan hasil wawancara dengan AKP I Wayan Subratha S.H.,M.H. beliau menyatakan Pelanggaran disiplin terbagi menjadi 2 kategori yaitu pelanggaran disiplin murni dan pelangaran disiplin tindak murni.

1. Pelanggaran disiplin murni adalah perbuatan yang dilakukan oleh anggota Kepolisian Negara Republik Indonesia yang melanggar peraturan peraturan kedinasan

2. Pelanggaran disiplin tidak murni adalah suatu perbuatan yang dilakukan oleh anggota Kepolisian Negara Republik Indonesia yang melanggar ketentuan ketentuan dalam Hukum Pidana. ${ }^{10}$

Anggota POLRI yang terlibat dalam praktek perjudian termasuk suatu jenis pelanggaran disiplin tidak murni karena didalam perbuatan pelanggaran disiplin telah terjadi perbuatan pidana yaitu terlibat dalam suatu praktek perjudian sebagaimana diatur dalam pasal 303 dan 303 bis KUHP.

\section{PENIUTUP}

\section{SIMPULAN}

1. Penyebab-penyebab terjadinya penyalahgunaan wewenang POLRI dalam pemberantasan tindak pidana judi dikarenakan kurangnya pengawasan yang optimal, karena setiap anggota POLRI berdasar pada TRIBRATA dan CATUR PRASETYA POLRI yang dimana mengatur pedoman moral dan penuntun nurani bagi setiap anggota POLRI serta dapat pula berlaku bagi pengemban fungsi kepolisian lainnya.

2. Akibat hukum bilamana anggota POLRI terlibat dalam praktek perjudian dikenakan sanksi disiplin dalam tingkat POLDA yang dimana berdasarkan kebijakan dari ANKUM/atasan yang berhak menghukum

\footnotetext{
${ }^{9}$ ibid. h. 12.

10 hasil wawancara dengan, bapak Wayan Subratha selaku KANIT RIKSA SUBBID PROVOS BIDPROPAM POLDA BALI, pada tanggal 17 Oktober 2017.
} 
dalam mengambil keputusan dalam proses secara pidana dan penjatuhan sanksi secara administratif.

\section{SARAN}

1. Seharusnya, perlu adanya penambahan masa pembinaan secara kepribadian, moral dan mental serta pengawasan setelah pembinaan, sehingga dapat sejalan kembali dengan nilai-nilai kode etik profesi POLRI, sehingga terciptanya insan dan institusi Polri yang professional serta dicintai rakyatnya dapat terlaksana. Baik buruknya institusi POLRI bergantung pada integritas moral yang tinggi pada setiap anggota POLRI

2. Bagi lembaga penegak hukum kepolisian mampu menciptakan penegakan hukum dan keadilan yang benar dan merata bagi anggota POLRI yang melakukan pelanggaran dan tindak pidana, agar citra polisi dan lembaga peradilan di masyarakat bisa mendapat apresiasi yang baik berkat kinerja yang dilakukan lembaga peradilan yang mengadili anggota POLRI.

\section{DAFTAR PUSTAKA}

\section{Buku}

Budiardjo,Miriam, 2008, Dasar-dasar Ilmu Politik, Gramedia Pustaka Utama, Jakarta.

Fuady, Munir, 2009, Teori Negara Hukum Modern (Rechtstaat), Refika Aditama, Bandung, 104.

Hadjon,Philipus M., 1998, Tentang Wewenang Pemerintahan (Bestuursbevoegdheid), Pro Justitia Tahun XVI Nomor 1, Januari 1998.

Pramutyas Varentina," Penjatuhan Hukuman Disiplin Polri Di Sekolah Polisi

Negara Purwokerto (Kajian Terhadap Penerapan PP Nomor 2 Tahun 2003 Tentang Peraturan Disiplin Anggota Kepolisian Republik Indonesia) Skripsi, Perpustakaan fakultas hukum Universitas Jendral Soedirman,Porwokerto.

Ridwan H.R., 2011, Hukum Administrasi Negara Edisi Revisi, Rajawali Pers, Jakarta. 


\section{Peraturan Perundang-Undangan}

Undang-Undang Negara Republik Indonesia No 7 Tahun 1974 Tentang

Penertiban Perjudian Lembaran Negara Tahun 1974 Nomor 54.

Undang-Undang Negara Republik Indonesia Nomor 2 Tahun 2002 Tentang

Kepolisian Negara Republik Indonesia Tambahan Lembaran

Negara Republik Indonesia Nomor 4168

Peraturan Pemerintah Republik Indonesia Nomor 2 Tahun 2003 Tentang

Peraturan Disiplin Anggota Kepolisian Negara Republik Indonesia

Tambahan Lembaran Negara Republik Indonesia Nomor 4256.

Peraturan Kepala Kepolisian Republik Indonesia Nomor 14 Tahun 2011

Tentang Kode Etik Profesi Kepala Kepolisian Republik Indonesia

Berita Negara Republik Indonesia Tahun 2011 Nomor 608.

\section{Wawancara}

Wawancara dengan, Bapak I Wayan Subratha KANIT RIKSA, SUBIT PROVOS di POLDA BALI, pada tanggal 17 Oktober 2017. 